\title{
Retrospective analysis of episiotomy prevalence
}

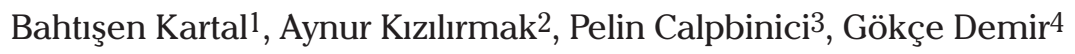 \\ 1Department of Nursing, Gaziosmanpaşa University Faculty of Health Sciences, Tokat, Turkey \\ 2Department of Nursing, Nevşehir Hacı Bektaş Veli University Semra and Vefa Küçük School of Health, Nevşehir, Turkey

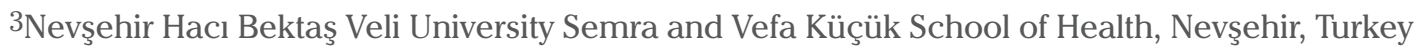 \\ 4Department of Nursing, Ahi Evran University School of Health, Kırşehir, Turkey
}

\section{Abstract}

Objective: This study was performed to determine the rate of episiotomy.

Material and Methods: This retrospective was conducted in 3 state hospitals located in 3 cities in the Central Anatolia region of Turkey. Ethics committee approval was received for this study. Also, institutional permissions from the institutions where the study was conducted were obtained before the study. The sample of the study consisted of 8587 women. The data of the study were collected by analyzing birth records in archive records.

Results: The average age of the women was $26.16 \pm 5.9$ years, the average number of deliveries was $2.19 \pm 1.2$, and $52.0 \%$ of the women who gave birth via vaginal delivery underwent episiotomy. The rate of episiotomy was found to be $93.3 \%$ in primipara women and $30.2 \%$ in multipara women. It was determined that neonatal weight did not affect the episiotomy rate, and that neonatal height was higher in deliveries with episiotomy and suture. Also, it was determined that as the age and parity of the women decreased, the rate of episiotomy increased.

Conclusion: The rate of episiotomy was observed to be high, especially in primipara women. (J Turk Ger Gynecol Assoc 2017; 18: 190-4)

Keywords: Episiotomy, prevalence, vaginal deliveries

Received: 28 December, 2016 Accepted: 1 August, 2017

\section{Introduction}

Episiotomy is a surgical incision applied to the bulbocavernosus muscle in the second phase of labor in order to make the delivery easier by enlarging the vaginal opening, to protect the tonus of the perineum, to prevent undesired vaginal fissures, and to enable easy, fast and safe delivery of the head of the fetus (1).

Surgical opening of the perineum was suggested for the first time in 1714 in order to prevent serious tears of the perineum (2). A significant increase in episiotomy rates was observed around the world (3). Despite being one of the most frequently administered surgical procedures in the world, the efficacy of episiotomy was introduced without strong scientific evidence (2). The World Health Organization (WHO) suggested that episiotomy should not be administered as routine practice (4), and in a bulletin published by the American College of Obstetricians and Gynecologists, episiotomy was reported to be restricted (5). Despite these suggestions, prevalence of episiotomy varies significantly between countries (6). The rate of episiotomy varies between $9.7 \%$ (the lowest) (Sweden) and $100 \%$ (the highest) (Taiwan) in both primipara and multipara women (7).

Episiotomy is suggested to be administered in conditions such as complicated vaginal deliveries (breech, shoulder dystocia, forceps, vacuum), incision-related scars in the genital area, poorly healed or $4^{\text {th }}$ degree tears, and fetal distress (8). There are different opinions about the applicability of episiotomy in addition to protecting maternal and infant health. While opinions about episiotomy's increasing Apgar score of the baby or decreasing perinatal asphyxia by shortening the second phase of delivery are not definite, there are also views that it does not prevent, or even increases, defects in the perineum (9). Also, in a comparison of limited use of episiotomy and routine episiotomy in deliveries without any complication, the WHO reported that episiotomy decreased posterior perineal 
trauma risk and prenatal trauma repair need, and that there was no difference between the two groups in terms of risks of vaginal and perineal trauma, pain, dyspareunia, and urinary incontinence (10).

It is indicated that routinely administered episiotomy causes postpartum early perineal complications and higher perineal pain scores (11-13), urinary inconsistencey is higher in the postpartum $3^{\text {rd }}$ month in women undergoing episiotomy (13), and the amount of blood loss is higher in the delivery (14). In another study, it was stated that with a decrease of episiotomy administration, anal sphincter lacerations decreased in vaginal deliveries (15).

The rate of perineal trauma is indicated to be high in countries where episiotomy is frequently administered (16-18). Moreover perineal trauma caused due to episiotomy can affect the sexuality and self-confidence of women $(19,20)$, and lead to perineal pain and infections $(21,22)$. There are also studies emphasizing that episiotomy has a protective role against the formation of $3^{\text {rd }}$ degree tears (14,23-25).

The study was conducted to retrospectively analyze the prevalence of episiotomy in vaginal deliveries in 3 state hospitals located in the Central Anatolia region of Turkey.

\section{Material and Methods}

\section{Study design and participants}

This retrospective study was conducted in state hospitals in 3 cities in the Central Anatolia region of Turkey. The records of 8649 women who gave birth between January $1^{\text {st }}$, and December 31st, 2013, were examined retrospectively. The data of 62 women were excluded due to a lack of information and 8587 women were included in the study. The data of the study were collected by examining birth registrations from archive records. The birth registrations involved information concerning the ages of the women, delivery methods, number of births, and the height and weight of the infants.

\section{Ethical aspect of the study}

Ethics committee approval was received for this study. Also, institutional permissions from the institutions where the study was conducted were obtained before the study.

\section{Statistical analysis}

The Statistical Package for Social Sciences (SPSS) 20 package programme was used to assess the data. Categorical measurements are given as number and percentage, and numerical measurements are given as mean and standard deviation. The chi-square and ANOVA test were used. Statistical significance was accepted as $\mathrm{p}<0.05$.

\section{Results}

It was determined that average age of the women was $26.16 \pm 5.9$ years, the average number of births was $2.19 \pm 1.2$, $34.6 \%$ were primipara, $76.4 \%$ of all women had vaginal deliveries, and $52.0 \%$ of the women who had vaginal deliveries gave birth with episiotomy. Also, 99.2\% of the deliveries were live births (Table 1).

The rate of episiotomy was determined as $93.3 \%$ in primipara women and as $30.2 \%$ in multipara women. The rate of suture delivery without episiotomy was $0.6 \%$ in primipara women, whereas this rate was $7.4 \%$ in multipara women. In the statistical analysis, a significant difference between the groups was determined $(\mathrm{p}<0.05)$ (Table 2$)$.

It was determined that neonatal weight did not affect the episiotomy rate, and neonatal height was higher in deliveries with episiotomy and suture. Moreover, as the age of the women decreased, the episiotomy rate increased. The episiotomy

Table 1. Distribution of the women based on demographic and obstetric characteristics

\begin{tabular}{|c|c|c|}
\hline Variables & \multicolumn{2}{|c|}{$\begin{array}{l}\text { Mean } \pm \text { standard } \\
\text { deviation }\end{array}$} \\
\hline Age (years) & \multicolumn{2}{|l|}{$26.16 \pm 5.9$} \\
\hline Number of births & \multicolumn{2}{|l|}{$2.19 \pm 1.2$} \\
\hline Obstetric history & Number & $\%$ \\
\hline Primipara & 2971 & 34.6 \\
\hline Multipara & 5616 & 65.4 \\
\hline \multicolumn{3}{|l|}{ Delivery method } \\
\hline Cesarean section & 2026 & 23.6 \\
\hline Vaginal & 6562 & 76.4 \\
\hline \multicolumn{3}{|l|}{ Vaginal delivery $(n=6562)$} \\
\hline Delivery with episiotomy & 3415 & 52.0 \\
\hline Delivery without episiotomy & 2818 & 42.9 \\
\hline Suture delivery without episiotomy & 329 & 5.1 \\
\hline
\end{tabular}

Table 2. Distribution of vaginal delivery-related characteristics of the women in terms of gravida number

\begin{tabular}{|l|l|l|l|l|l|l|}
\hline \multirow{2}{*}{$\begin{array}{l}\text { Delivery } \\
\text { related } \\
\text { characteristics }\end{array}$} & \multicolumn{4}{|c|}{ Gravida } & \multirow{2}{*}{$\chi^{\mathbf{2}}$} & p \\
\cline { 2 - 5 } & \multicolumn{2}{|l|}{ Primipara } & \multicolumn{2}{|l|}{ Multipara } & & \\
\cline { 2 - 5 } & $\mathbf{n}$ & $\mathbf{\%}$ & $\mathbf{n}$ & $\mathbf{\%}$ & & \\
\hline $\begin{array}{l}\text { Delivery with } \\
\text { episiotomy }\end{array}$ & 2116 & 93.3 & 1299 & 30.2 & \multirow{2}{*}{2366.8} & $<\mathbf{0 . 0 0 1}$ \\
\hline $\begin{array}{l}\text { Delivery without } \\
\text { episiotomy }\end{array}$ & 138 & 6.1 & 2680 & 62.4 & & \\
\hline $\begin{array}{l}\text { Suture delivery } \\
\text { without } \\
\text { episiotomy }\end{array}$ & 13 & 0.6 & 316 & 7.4 & & \\
\hline
\end{tabular}


rate of women with a low number of births was high and the difference between the groups was statistically significant $(\mathrm{p}<0.05)$ (Table 3).

\section{Discussion}

The WHO reported that episiotomy should be restricted in deliveries without complications. In the same study, it was also stated that restrictive episiotomy was more advantageous compared with routine episiotomy, and there was less posterior perineal trauma, and fewer sutures and complications in restrictive episiotomy (2).

In addition to the $\mathrm{WHO}$ and other authorities, patients for whom episiotomy should be administered are clearly defined in the safe motherhood module published by the General Directorate of Maternal and Infant Health and Family Planning and used in in-service training of personnel. Episiotomy is suggested in order to step up the delivery in cases with fetal distress,

Table 3. Distribution of vaginal delivery characteristics in terms of different variables

\begin{tabular}{|c|c|c|c|}
\hline Variables & $\begin{array}{l}\text { Mean } \pm \text { standard } \\
\text { deviation }\end{array}$ & $\mathbf{F}$ & $\mathbf{p}$ \\
\hline \multicolumn{4}{|c|}{ Neonatal weight (grams) } \\
\hline $\begin{array}{l}\text { Delivery with } \\
\text { episiotomy }\end{array}$ & $3252.04 \pm 966.13$ & \multirow{3}{*}{0.44} & \multirow{3}{*}{0.639} \\
\hline $\begin{array}{l}\text { Delivery without } \\
\text { episiotomy }\end{array}$ & $3238.92 \pm 742.58$ & & \\
\hline $\begin{array}{l}\text { Suture delivery without } \\
\text { episiotomy }\end{array}$ & $3281.52 \pm 50.01$ & & \\
\hline \multicolumn{4}{|l|}{ Neonatal height $(\mathrm{cm})$} \\
\hline $\begin{array}{l}\text { Delivery with } \\
\text { episiotomy }\end{array}$ & $50.07 \pm 1.47$ & \multirow{3}{*}{4.85} & \multirow{3}{*}{0.008} \\
\hline $\begin{array}{l}\text { Delivery without } \\
\text { episiotomy }\end{array}$ & $49.91 \pm 2.50$ & & \\
\hline $\begin{array}{l}\text { Suture delivery without } \\
\text { episiotomy }\end{array}$ & $50.02 \pm 2.78$ & & \\
\hline \multicolumn{4}{|c|}{ Age of the women (years) } \\
\hline $\begin{array}{l}\text { Delivery with } \\
\text { episiotomy }\end{array}$ & $23.62 \pm 5.18$ & \multirow{3}{*}{623.33} & \multirow{3}{*}{0.001} \\
\hline $\begin{array}{l}\text { Delivery without } \\
\text { episiotomy }\end{array}$ & $28.49 \pm 5.78$ & & \\
\hline $\begin{array}{l}\text { Suture Delivery without } \\
\text { episiotomy }\end{array}$ & $27.37 \pm 5.74$ & & \\
\hline \multicolumn{4}{|l|}{ Number of births } \\
\hline $\begin{array}{l}\text { Delivery with } \\
\text { episiotomy }\end{array}$ & $1.53 \pm 0.8$ & \multirow{3}{*}{1632.46} & \multirow{3}{*}{0.001} \\
\hline $\begin{array}{l}\text { Delivery without } \\
\text { episiotomy }\end{array}$ & $3.01 \pm 1.3$ & & \\
\hline $\begin{array}{l}\text { Suture delivery without } \\
\text { episiotomy }\end{array}$ & $2.42 \pm 0.8$ & & \\
\hline
\end{tabular}

in order to prevent intracranial hemorrhage with forceps, vacuum applications, premature or breech delivery, and in cases where excertion of the mother's strength during delivery should be prevented (i.e. cardiac failure), and if there is a risk of $3^{\text {rd }}$ degree perineum tears (especially when $3^{\text {rd }}$ degree tears occurred during a previous delivery) (26).

In the present study, it was determined that more than half of the women (52.0\%) having vaginal deliveries underwent episiotomy, and $93.3 \%$ of the primipara women and $30.2 \%$ of the multipara women received episiotomy. The suture delivery rate was determined to be higher in multipara women.

In a study conducted by Çalışkan et al. (27) (2003), it was reported that the episiotomy rate was $74.2 \%$. In another study conducted in Turkey by Karaçam et al. (12), it was reported that episiotomy was performed in $64 \%$ of vaginal deliveries $(95 \%$ of first deliveries, $48 \%$ of second deliveries, $12 \%$ of third and subsequent deliveries). In another Turkish study, episiotomy was reported to be administered in $92 \%$ of primipara women and $72 \%$ of multipara women (28).

In some countries, the episiotomy rate has decreased over the years. The episiotomy rate was $60.9 \%$ in all vaginal deliveries in 1979 in the United States of America, but the rate decreased to $24.5 \%$ in 2004 ; (15) in a study conducted in Thomas Jefferson University Hospital, the episiotomy rate decreased from $69.6 \%$ in 1983 to $19.4 \%$ in 2000 (29), and in a study conducted in Hong Kong, the rate decreased from $73 \%$ in 2003 to $27 \%$ in 2008 (30). However, the ideal rate of episiotomy is still not clear (15). There are differences between episiotomy rates depending on the countries. In a study conducted in primipara women in Nigeria, the rate of episiotomy was determined as $62.1 \%$ (6). In contrast, the rate of episiotomy was $40.6 \%$ in primipara women in a study conducted in Italy (31). Trinh et al. (32) (2013) evaluated the rate of episiotomy among women born in Vietnam and Australia between 2001 and 2010. In Australia, they found that the episiotomy rate was $27 \%$ in Australian-born primipara women, and $48 \%$ in Vietnamese-born women. In a study conducted in Oman, the rate of episiotomy was 66\% (33).

Perineal trauma is described as damage that occurs in the genital region or due to a surgical incision or episiotomy during delivery $(20,34)$. Even though there are a number of studies indicating that episiotomy is defined as a cause of birth trauma, as well as disadvantages of its administration, the episiotomy rate was high in the present study, as it is in developing countries. Episiotomy is administered in almost all primipara women regardless of the presence/ absence of complications with delivery, it is almost a routine administration for primipara women. In Turkey, deliveries performed at hospitals are performed in the lithotomy position and practices providing flexibility to the perineum are applied 
in very few clinics. Episiotomy administration procedures should be adapted to all healthcare personnel who assist delivery through in-service training and the necessity of avoiding routine administration should be emphasized. In addition, increasing alternative practices such as massage and restricting episiotomy in vaginal deliveries will enable a decrease in the episiotomy rate.

Ethics Committee Approval: Ethics committee approval was received for this study from the ethics committee of Nevşehir Hacı Bektaş Veli University (No: 2014.02.02).

Informed Consent: Written informed consent wasn't obtained from patients who participated in this study because it's a retrospective study.

\section{Peer-review: Externally peer-reviewed.}

Author Contributions: Concept - B.K., A.K., P.C.; Design - B.K., A.K.; Supervision - B.K., A.K., P.C., G.D.; Materials - B.K., A.K., P.C., G.D.; Data Collection and/or Processing - B.K., A.K., P.C., G.D.; Analysis and/or Interpretation - B.K., A.K., P.C.; Literature Review - B.K, A.K., P.C.; Writer - B.K. A.K., P.C., G.D.; Critical Review - B.K., A.K., P.C., G.D.

Conflict of Interest: No conflict of interest was declared by the authors.

Financial Disclosure: The authors declared that this study has received no financial support.

\section{References}

1. Taşkın L. Doğum ve Kadın Sağlığı Hemşireliği. 12th ed. Ankara: Akademisyen Tıp Bookstore, Özyurt Press. Ankara; 2014.

2. Carroli G, Belizan J. Episiotomy for vaginal birth (Review). The Cochrane Collaboration. The Cochrane Library 2007; 4: 2. http:// apps.who.int/rhl/reviews/langs/CD000081ru.pdf

3. Langrová P, Vrublová Y. Relationship between episiotomy and prevalence of urinary incontinence in women 2-5 years after childbirth. Cent Eur J Nurs Midw. 2014; 5: 94-8. http://periodika.osu. cz/cejnm/dok/2014-03/1-langrova-vrublova.pdf

4. Liljestrand J. Episiotomy for vaginal birth: RHL commentary. Geneva: World Health Organization Reproductive Health Library [cited 2016 May 9] (2003). http://apps.who.int/rhl/pregnancy childbirth/childbirth/2nd_stage/jlcom/en/

5. American College of Obstetricians and Gynecologists. ACOG recommends restricted use of episiotomies; 2006. [cited 2016 May 5]. Available from: http://www.acog.org/About-ACOG/News-Room/ News-Releases/2006/ACOG-Recommends\%20Restricted-Use-ofEpisiotomies.

6. Izuka EO, Dim CC, Chigbu CO, Obiora-Izuka CE. Prevalence and predictors of episiotomy among women at first birth in Enugu, south east Nigeria. Annals of Medical And Health Sciences Research 2015; 4(6): 928-32. https://www.ncbi.nlm.nih.gov/pmc/ articles/PMC4250993/

7. Graham ID, Carroli G, Davies C, Medves JM. Episiotomy rates around the world: an update. BIRTH 2005; 32: 219-23. http://onlinelibrary. wiley.com/doi/10.1111/j.0730-7659.2005.00373.x/epdf
8. World Health Organization (2007). Reproductive Health. Managing complications in pregnancy and childbirth: a guide for midwives and doctors; [cited 2016 May 9]. Available from: http://apps.who. int/iris/bitstream/10665/43972/1/9241545879_eng.pdf.

9. Ayhan A, Bozdağ G, Deren Ö. Birth Physiology and Vaginal Birth Basic Gynecology and Obstetrics 2st ed. Ankara: Ayrıntı Press; 2008.

10. Carroli G, Mignini L. Episiotomy for vaginal birth. Cochrane Database Syst 2009. Rev 1(1). http://onlinelibrary.wiley.com/ doi/10.1002/14651858.CD000081.pub2/pdf/abstract

11. Coutada RS, Nogueira-Silva C, Rocha A. Episiotomy: early maternal and neonatal outcomes of selective versus routine use episiotomia: resultados maternos e neonatais precoces do uso seletivo versus generalizado. Acta Obstet Ginecol Port. 2014; 8: 126-34. http://www.fspog.com/fotos/editor2/07_2014-2aogp-d-13-00049.pdf

12. Karaçam Z, Ekmen H, Çalışır H, Şeker S. Prevalence of episiotomy in primiparas, related conditions, and effects of episiotomy on suture materials used, perineal pain, wound healing 3 weeks postpartum, in Turkey: A prospective follow-up study. Iran J Nurs Midwifery Res 2013; 18: 237-45.

13. Chang SR, Chen KH, Lin HH, Chao YM, Lai YH. Comparison of the effects of episiotomy and no episiotomy on pain, urinary incontinence, and sexual function 3 months postpartum: a prospective follow-up study. Int J Nurs Stud 2011; 48: 409-18.

14. Lam KW, Wong HS, Pun TC. The practice of episiotomy in public hospitals in Hong. Hong Kong Med J 2006; 12: 94-8.

15. Frankman EA, Wang L, Bunker CH, Lowder JL. Episiotomy in the United States: has anything changed? Am J Obstet Gynecol 2009; 200: 573.

16. McCandlish R, Bowler U, van Asten H, Berridge G, Winter C, Sames $\mathrm{L}$, et al. A randomised controlled trial of care of the perineum during second stage of normal labour. Br J Obstet Gynaecol 1998; 105: 1262-72.

17. Albers L, Garcia J, Renfrew M, McCandlish R, Elbourne D. Distribution of genital tract trauma in childbirth and related postnatal pain. Birth 1999; 26: 11-7.

18. Mayerhofer K, Bodner-Adler B, Bodner K, Rabl M, Kaider A, Wagenbichler $\mathrm{P}$, et al. Traditional care of the perineum during birth. A prospective, randomized, multicenter study of 1,076 women. J Reprod Med 2002; 47: 477-82.

19. Renfrew MJ, Hannah W, Albers L, Floyd E. Practices that minimize trauma to the genital tract in childbirth: a systematic review of the literature. Birth 1998; 25: 143-60.

20. Johanson R. Perineal massage for prevention of perineal trauma in childbirth. Lancet 2000; 355: 250-1.

21. Balkaya Akdolun N. Postpartum Dönemde Annelerin Bakım Gereksinimleri ve Ebe-Hemşirenin Rolü. C. Ü. Hemşirelik Yüksekokulu Dergisi 2002; 6: 42-9.

22. Hartmann K, Viswanathan M, Palmieri R, Gartlehner G, Thorp Jr, Lohr KN. Outcomes of routine episiotomy: a systematic review. JAMA 2005; 293: 2141-8.

23. Handa VL, Danielsen BH, Gilbert WM. Obstetric anal sphincter lacerations. Obstet Gynecol 2001; 98: 225-30.

24. de Leeuw JW, Struijk PC, Vierhout ME, Wallenburg HC. Risk factors for third degree perineal ruptures during delivery. BJOG 2001; 108: 383-7.

25. Rodriguez A, Arenas EA, Osorio AL, Mendez O, Zuleta JJ. Selective vs routine midline episiotomy for the prevention of third-or fourthdegree lacerations in nulliparous women. Am J Obstet Gynecol 2008; 198: 285

26. Republic of Turkey Ministry of Health General Directorate of Maternal and Infant Health and Family Planning. 2009. Safe Motherhood Participant Book. Ankara: 2016. 
27. Çalışkan E, Öztürk N, Akyan B, Dilbaz B, Yalvaç S, Haberal A Analysis of 47145 deliveries in a tertiary center: an epidemiological view. Gynecology Obstetrics \& Reproductive Medicine 2003; 9: 8891.

28. Hotun-Şahin N, Yıldıım G, Aslan E. Evaluating the second stages of deliveries in a maternity hospital, Turkiye Klinikleri J Gynecol Obst 2007; 17: 37-43.

29. Goldberg J, Holtz D, Hyslop T, Tolosa JE. Has the use of routine episiotomy decreased? Examination of episiotomy rates from 1983 to 2000. Obstet Gynecol 2002; 99: 395-400.

30. Lai CY, Cheung HW, Hsi Lao TT, Lau TK, Leung TY. Is the policy of restrictive episiotomy generalisable? A prospective observational study. J Matern Fetal Neonatal Med 2009; 22: 1116-21.
31. Cromi A, Bonzini M, Uccella S, Serati M, Bogani G, et al. Provider contribution to an episiotomy risk model. J Matern Fetal Neonatal Med 2015; 28: 2201-6.

32. Trinh AT, Khambalia A, Ampt A, Morris JM, Roberts CL. Episiotomy rate in Vietnamese-born women in Australia: support for a change in obstetric practice in Viet Nam. Bull World Health Organ 2013; 91 : 350-6.

33. Al-Ghammari K, Al-Riyami Z, Al-Moqbali M, Al-Marjabi F, AlMahrouqi B, Al-Khatri A, et al. Predictors of routine episiotomy in primigravida women in Oman. Appl Nurs Res 2016; 29: 131-5.

34. Albers LL, Sedler KD, Bedrick EJ, Teaf D, Peralta P. Factors related to genital tract trauma in normal spontneous vaginal births. Birth 2006; 32: 94-100. 